Iskra Christova-Balkanska, Ph.D.

Economic Research Institute at the Bulgarian Academy of Sciences iskbal@bas.bg

\title{
BULGARIAN ECONOMIC DEVELOPMENT AND EU INTEGRATION
}

\begin{abstract}
The present research is devoted to the "economic catch-up" and the convergence of the macroeconomic indicators and the living standards of Bulgaria and the new EU Member States from Central and Eastern Europe with those of the developed economies of the EU. It is clarified that the economic and social development and territorial integrity of the EU are dependent on the successful convergence of the Member States and not only on that of the separate levels. With the entry into force of the Maastricht Treaty, compliance with the nominal economic indicators becomes a prerequisite for entry into the euro area. The establishment of the Economic and Monetary Union (EMU) is the most significant element of economic integration into the EU. The question arises: to what extent does the EMU contribute to the economic convergence of the Member States? The main question remained how do the economic development of Bulgaria is assisting the convergence process of Bulgaria to the EC economies.
\end{abstract}

Keywords: economic convergence, neoliberal model of the Economic and Monetary Union (EMU), differences in gross domestic product $(G D P)$ per capita in the EU.

JEL: Q47 


\section{DOES THE ECONOMIC AND MONETARY UNION (EMU) CONTRIBUTE TO THE CONVERGENCE OF THE ECONOMIES IN THE EURO AREA?}

"Economic convergence" is a complex concept that reflects various aspects of the economic and political life in the EU. The convergence and cohesion policy of the EU countries and regions is based on Article 3 of the EU Treaty, which states that the EU "shall work for the sustainable economic and social development of Europe, based on balanced economic growth and price stability" and therefore "it shall promote economic, social and territorial cohesion, and solidarity among Member States". The cohesion or convergence is directed towards the overall sustainable and harmonious development of the $\mathrm{EU}$ and a strong emphasis is placed on the reduction of the economic and social disparities between the different EU regions.

After the entry into force of the European Single Market and at an earlier stage of economic integration, "economic convergence" means the approximate convergence of the GDP per capita of the EU regions and the EU Member States, which in turn means a convergence of income levels. The sustainable development and the economic convergence of the regions and countries are expressed in real terms through the introduction and operation of the European structural and regional funds (ESRF). They contribute to the coordination of the economic policy of the EU. The ESRF are among the main tools for tackling major economic, financial and social differences between the Member States. Funding through the ESRF is important for every EU Member State because they are aimed at funding infrastructure projects, retraining the workforce, introducing innovative practices in manufacturing and agriculture, developing schemes for saving natural resources and energy, etc. The ESRF aid the development of priority economic sectors in every Member State, but the most substantial financial and technical support is provided to the "less developed regions" - in those countries where the GDP is below $75 \%$ of the EU average.

The entry into force of the Economic and Monetary Union (EMU) is a new higher stage of economic, monetary and financial integration. Unlike the integration of the trade in goods and services through the 
entry into force of the Single Market, the EMU puts limitations on the ability to make sovereign economic decisions. The monetary policy is determined by the European Central Bank (ECB) and the countries cannot use the instruments of monetary policy in order to regulate certain economic and social goals on a national level. The term "economic convergence" acquires another meaning upon entering into a new, higher stage of economic, monetary and financial integration, wherein, apart from the GDP per capita, five additional macroeconomic indicators (the Maastricht criteria), such as the budget deficit and the public debt in relation to GDP, the inflation rate and the movement of the mid-term interest rate, become important for economic cohesion and convergence. By entering the euro area, the EU Member States take on the obligation to respect certain limits to the allowed level of deviation from the above mentioned macroeconomic variables, with the exception of countries that have not adopted the common European currency, such as Denmark, Sweden and the UK. (In 2016, Britain voted to withdraw its membership from the EU following a referendum on the topic of staying or leaving the EU.)

If we examine the Lisbon Strategy and the Europe 2020, the concept of "economic convergence" is once again enriched with the inclusion of socially significant socioeconomic indicators such as the level and quality of education, employment, scientific and technical development, the reduction of poverty in Europe and other indicators that characterize the standard and quality of life. The socioeconomic indicators and targets of economic development are determined by the Executive official authorities in every Member State. They sign into a socioeconomic level program, which is discussed and coordinated by the European Commission (EC) and other relevant institutions in the EU. Achieving the socioeconomic goals of the country is part of the EU coordinated efforts to achieve the convergence of the economic development of the Member States, which is a prerequisite for entering into a new, higher stage of integration in all areas of economic life.

The global financial and economic crisis and the sovereign debt crisis in the euro area countries in 2010 are changing the macroeconomic and social framework of the EU. The sovereign debt crisis in Europe 
brought to light the significant structural economic and financial problems of the euro area. European banks are experiencing serious liquidity problems which can be overcome mainly with the help of public funding and funding from the ECB. The limiting of the credits granted by banks to the real sector of the economy is forcing many European companies to reduce their import-export operations and investments. This affects the economy and trade of almost all the new Member States that entered the EU in 2004 and 2007.

The deterioration in the ratio of domestic debt to GDP in Spain, Portugal and Greece substantially disrupts the social, economic and financial stability in the euro area. These adverse events require the application of specific measures aimed at introducing a series of prudential and effective measures of supervision over the banking and financial sector in the euro area countries and the EU. The measures taken in order to curb the high domestic debt of the countries form the basis of the "European fiscal pact" program, the "European semester", etc. In order to curb the accumulation of new debt, the indebted countries are forced to pursue a restrictive budgetary policy, to impose restrictions over domestic expenditure and to stimulate the attraction of funds in the revenue part of the budget. These policies are aimed at reducing the number of economic and social programs of the governments. The economic business cycle varies from country to country and this also suggests that, in the short term, the recovery of the economies in the period after the economic and debt crisis in Europe cannot happen simultaneously in all EU Member States.

The economic and financial problems accumulated by the EU countries, as well as the difficulties that they overcome, indicate that the Maastricht criteria, as benchmarks for a sustainable and convergent economic policy, are not followed. The accumulation of economic imbalances in some EU countries shows that the differences between the macroeconomic indicators in the different EU Member States are deepening and the objectives of economic and social cohesion are postponed in time.

The main imbalance of the EMU is rooted in the lack of a unified fiscal and budgetary policy in the EU. For example, if the economic growth in a Member State is relatively higher, this suggests that the 
inflation is likely to grow. Due to the lack of sovereignty in the monetary policy, the Member State has no right to unilaterally raise the medium-term interest rate. Conversely, if the economic growth in a Member State deteriorates, it cannot unilaterally devalue (or depreciate) its currency in order to improve the competitiveness of production. The single monetary policy does not allow unilateral countermeasures on the part of the state - neither when there is higher inflation, nor when there is a fall in economic growth - which is the reason behind the occurrence of asymmetry in the economic business cycle of the countries in the euro area. Because they are at different levels of economic activity - recovery or stagnation - the Member States do not have the freedom to guide economic policy towards a restrictive or expansionary monetary policy. According to the theory of monetary integration, the asymmetric shocks and the differences in the economic business cycle can be adjusted and controlled by fiscal policy. The countries that are experiencing a crisis have the opportunity to stimulate their economies by cutting taxes and increasing public spending, while the countries that are expecting an economic downturn and problems in the banking and financial sector should increase taxes and shrink public spending. The difficulties of overcoming the asymmetries in economic development, as well as the differences in the structure of the different EU economies, are one of the prerequisite for the slow overcoming of the crisis trends in the economies of the EU countries. There are still some considerable discrepancies, as some of the countries in the euro area are experiencing considerable difficulties in servicing the high domestic debt, while others show signs of economic recovery, because the economic growth rates are low but positive. Euro area interest rates are low and there is a risk - if the government debt of some countries is growing, this will affect the balance on the European financial markets. The growth of the risk margin that is charged on the debt securities of countries with high domestic debt means that the principal amount and the interest rates on it are also rising - this is a process that can spiral out of control and affect the stability of the euro area.

The economic crisis and the sovereign debt crisis in Europe bring into question the sustainability and appropriateness of Member States having to complying with the strictly fixed Maastricht criteria. They 
are undoubtedly a guarantee of compliance with the monetary and financial discipline, but, at the same time, the deviation from the fixed parameters of the macroeconomic indicators of the euro area countries shows the need for some reforms. Therefore, the fixed Maastricht criteria are at the core of the discussions concerning the impact of the level of the nominal economic variables on the actual economic situation of the Member States. The only mechanism that could act as a counterbalance to the economy is called "internal devaluation". "Internal devaluation" means cutting labor costs, a rise in unemployment and lower public and social costs. It is a substitute for the devaluation of the national currency, but this substitute is dangerous for the social sector of the economy because it gives rise to the deterioration of living standards and it impedes the process of economic, social and territorial cohesion. Internal devaluation or the waste of human capital contributes significantly to the strengthening of the separation processes in the euro area and for the deepening of the differences in both the financial welfare and the real sector.

A major question, which is also important for the deepening of the monetary financial integration, is how to overcome the difference in the economic business cycle and how the countries can counteract the occurrence of unanticipated external economic and other shocks, given that euro area countries have a common monetary and currency policy, but at the same time they lack shared fiscal and budgetary responsibility. Addressing these issues is left to the prerogatives of the supranational political and economic authorities in the EU, which introduce measures for strengthening the supranational forms of regulation.

The question that stands is: what are the ways of effective economic coordination and convergence in an economic community which is moving at different speeds and has a different economic structure. In the post-crisis period, the differences in the economic development of the EU countries continue to deepen, but the European Commission (EC) tries to give a new meaning to the term "economic convergence" by extending the scope of the observed indicators. The macroeconomic imbalances are placed under heightened supervision, as eleven indicators are being monitored, including the current account of the balance of payments, the competitiveness of the 
economy, the corporate debt, the debt and over-indebtedness of households, etc.

The economic convergence of the EU economies is a complicated and complex concept and it reflects the evolution of the EU integration process. It boils down to several areas, namely: a) real convergence of incomes, relative equalization of living standards, increasing employment, improving energy efficiency and other factors; b) convergence of policies, such as fiscal policy, monetary policy, social policy and central bank independence.

\section{ECONOMIC CONVERGENCE BETWEEN BULGARIA AND OTHER EU MEMBER STATES}

\section{Nominal economic variables and the convergence of Bulgaria}

The economic convergence in relation to Bulgaria's accession, firstly to the Exchange Rate Mechanism II (ERMII), and secondly to the euro area, represents the evolution of the main macroeconomic indicators which act as convergence criteria in accordance with the Treaty on the Functioning of the European Union (Maastricht). These criteria measure the nominal economic convergence that constitutes the first part of the assessment of the economic convergence of Bulgaria.

The Bulgarian economy has undergone impressive changes during the economic transition from a central to a market economy. The years of transition to a market economy are characterized by extreme economic and political instability. The monetary and fiscal policies applied are aimed at developing the private sector of the economy, which is experiencing a series of economic shocks due to the unsustainable and chaotic development of the Bulgarian economy in the early years of the transition. The transformation of social and economic relations strongly influences the political and economic system in the country.

The applied economic and monetary policies, coupled with the weak financial and banking sector lie at the heart of a series of economic and financial shocks that affect economic growth. The culmination of 
this inconsistent monetary and fiscal policy is the outbreak of the banking crisis in the years 1995-1996. Subsequently, the adoption of the Currency Board in 1997 stabilized the economic system and the payment system in the country.

Bulgaria's integration into the EU structures (on 1.01.2007) is a positive stimulus for economic development. The economic growth is improving thanks to increased private consumption, investment in the economy, the reduction of unemployment and the increase in exports. The stabilization of the Bulgarian economy is also due to the favorable international economic environment in Europe.

Under the Currency Board regime, Bulgaria maintains a strict financial discipline. There is a budget surplus of 3\% of the GDP. The financial discipline allows for tax cuts and this policy is geared towards attracting investments by local and foreign investors into the economy. It helps to mitigate the burden of taxes on the population. Under the Currency Board regime, the lack of monetary policy is compensated by the accumulation of currency reserves in the Bulgarian National Bank (BNB). The currency reserves act as a buffer in case of a liquidity shortage or other external shocks.

The bank credits to businesses contribute to the modernization of the industrial sector, the increase of production and the creation of jobs. The bank credits to households make the expansion of domestic consumption possible, while at the same time there is an increase in domestic demand. These processes increase the level of inflation and the value of the Bulgarian lev is really rising in relation to that of the euro. In the years 2005-2008, the foreign trade volume increased, with imports exceeding exports. As a result, the current account deficit of the balance of payments is growing. The external current account deficit of the balance of payments increased to a double-digit number, as opposed to the GDP before the crisis. The current account deficit is financed by the inflow of FDI. After 2002, the volume of the accumulated FDI and the domestic consumption contribute to the GDP growth. The inflow of foreign capital contributes to the overheating of the economy and the sustainable increase in fixed asset prices. Overall, the real economic growth amounts to 5\% annually in the years 2003-2008. GDP growth, increased consumption, investment 
activity and lower taxes affect the occurrence of a current account deficit of the balance of payments and lie at the core of the relative decline in the competitiveness of Bulgarian exports (Macroeconomic Imbalances, Bulgaria, 2014). The Bulgarian governmental authorities pursue policies aimed at reducing budget deficits and government debt. In comparison with other new EU Member States (the Czech Republic, Hungary, Latvia, Lithuania, Poland and Romania), which implement an expansionary fiscal policy in order to stimulate GDP growth, which lead to the accumulation of substantial structural budget deficits in 2007, (ECB Monthly Bulletin, July 2010). In the precrisis period, Bulgaria experiences a period of a very rapid accumulation of imbalances, which is also related to the economic reforms carried out in relation to the process of Bulgaria's integration in the EU.

The main concerns for the macroeconomic stability stem from the growing current account deficit of the balance of payments and the increase in domestic credit, and this trend exacerbates the domestic economic imbalances. Similarly, before the crisis the economies of the Baltic EU Member States are experiencing a more rapid growth, but this growth is unsustainable, which leads to an increase in production in comparison to the Western European countries. The differences in economic growth between the new EU Member States and the euro area countries deepen the macroeconomic imbalances.

It could be argued that, as a lagging economy, Bulgaria is achieving higher growth rates in comparison to the euro area countries, which theoretically allows for the assertion that the country is in a position of catching-up, it is achieving higher growth rates and it is in the process of economic convergence.

The economic crisis of 2008-2009 gives rise to a sharp decline in the developed European economies. It is felt in Bulgaria much later when the orders from the major trading partners of Bulgaria shrink and the volume of FDI falls abruptly. Businesses cut costs and shrink domestic production, which leads to an increase in unemployment and a decrease in domestic consumption and investments. The banks tighten the conditions for granting credits to businesses and households, and the interest rates on credits greatly increase, which 
leads to an increase in the indebtedness of businesses and households. The decline in bank credit and the reduction of investments also contribute to the sharp decline in the industry.

The economic situation changes during the post-crisis period. Economic growth fluctuates around 1\%. Many sectors of the economy are slow to recover from the economic downturn due to the low level of local and foreign investment, the weak domestic and foreign demand for Bulgarian goods and the weak domestic consumption.

Although in the post-crisis period employment in all major sectors of the economy is improving, unemployment among young people with a lower level of education and qualification remains relatively high, as job positions disappear during the crisis. In 2014, the workers aged between 15 and 64 years of age amount to 2.9 million people - their number has increased by $1.3 \%$ compared to 2013 . Employment is growing in the major sectors of the economy with the exception of trade and transport. The decline in unemployment in 2014 is lower than the average unemployment rate in the EU, which amounts to $10.7 \%$ in 2014.

The contraction in domestic demand leads to a decline in inflation. The average annual inflation rate decreased from 1.0\% in May 2013 to - 2.1\% in February 2014, reaching -1.3\% in April 2014 (Convergence Report June 2014). The deflation registered in Bulgaria reflects the ongoing stagnation in production, the reduced consumption, the weak bank credit and the negative impact of the prices of basic raw materials and energy (Table 1).

Weak domestic demand remains the determining factor for the level of economic growth. In 2014, the private consumption is stabilized, mainly due to the reduction in interest rates by commercial banks and the decline in oil prices (2015). An alarming factor indicating stagnation in industrial production is the fact that gross capital formation has remained at the same level since 2012 (Table 1). The surplus in the current account deficit of the balance of payments that amounted to $0.1 \%$ of the GDP in 2011 became a deficit of $1.1 \%$ of the GDP in 2012. This is the result of weaker exports in 2012 and the need to import the goods necessary for the construction of large 
infrastructure projects. The trade deficit is also melting and in recent years it has been hovering around 5\% due to the decrease in domestic consumption and industrial production. In the period between January 2014 and January 2016 exports from Bulgaria amount to 3.7 billion euro on average. Export growth gives rise to the expectation that it plays the role of an engine that will liven up the Bulgarian economy. In the post-crisis period, those economic sectors of the Bulgarian economy that are export-oriented overcome the effects of the crisis more quickly. This is due to the fact that Bulgarian exports occupy specific niches in the international market of goods and services, allowing exports to rise in 2013, after which they once again declined.

Table 1. Main macroeconomic indicators for Bulgaria

\begin{tabular}{|l|c|c|c|c|c|c|c|c|c|}
\hline Indicators & $\mathbf{2 0 0 8}$ & $\mathbf{2 0 0 9}$ & $\mathbf{2 0 1 0}$ & $\mathbf{2 0 1 1}$ & $\mathbf{2 0 1 2}$ & $\mathbf{2 0 1 3}$ & $\mathbf{2 0 1 4}$ & $\mathbf{2 0 1 5}$ \\
\hline Real GDP (y-0-y) (\%) & 5.8 & -5.5 & 0.7 & 1,6 & 0,2 & 1.3 & 1.6 & 3,0 \\
\hline $\begin{array}{l}\text { Gross capital formation (y-0- } \\
\text { y) }\end{array}$ & 22.0 & - & - & -4.6 & 2.0 & -0.1 & 2.3 & -2.3 \\
\hline $\begin{array}{l}\text { Budget deficit (-) / surplus } \\
\text { (+)\% of GDP }\end{array}$ & & & & $-2,0$ & $-0,3$ & $-0,4$ & $-5,4$ & $-2,1$ \\
\hline $\begin{array}{l}\text { Government debt } \\
\text { (Maastricht debt) \% of GDP }\end{array}$ & & & & 15,3 & 16,8 & 17,1 & 27,0 & 26,7 \\
\hline $\begin{array}{l}\text { Export of goods and services } \\
\text { (y-o-y)\% }\end{array}$ & 2.5 & - & 17.2 & 34,4 & 3,2 & 7,8 & $-0,9$ & 4,2 \\
\hline $\begin{array}{l}\text { Import of goods and services } \\
\text { (y-o-y)\% }\end{array}$ & 4.9 & - & 4.1 & 22,4 & 8,8 & 2,0 & $-1,4$ & 3,1 \\
\hline $\begin{array}{l}\text { Inflation (HICP) average (y- } \\
\text { o-y) (\%) }\end{array}$ & 12.0 & 2.5 & 2.9 & 3.4 & 2.4 & 0.4 & -1.6 & $-1,1$ \\
\hline Unemployment rate (\%) & 5.6 & 6.8 & 10.3 & 10,4 & 11,4 & 11,8 & 10,7 & 10 \\
\hline $\begin{array}{l}\text { Current account of the } \\
\text { balance of payments (\% of } \\
\text { GDP) }\end{array}$ & -23.1 & -8.9 & - & 0.3 & $-0,9$ & 1,3 & 0,1 & 0,4 \\
\hline Trade balance (\% of GDP) & - & -8.2 & - & $-6,6$ & $-9,6$ & $-7,0$ & -6.5 & $-5,9$ \\
\hline Long-term interest rate ** & 20.6 & & & 5,36 & 4,50 & 3,47 & 3,35 & 2,49 \\
\hline
\end{tabular}

* Annual percentage change

(y-o-y) - change compared with the previous year (or period) ** Long-term interest rate for assessing the degree of convergence Source: NSI, BNB

The post-crisis development of the Bulgarian economy shows that Bulgaria covers and even surpasses some Eastern European countries 
in terms of the implementation of the Maastricht criteria, which are a prerequisite for a full membership in the Economic and Monetary Union (EMU). Under the criterion of "Harmonized Index of Consumer Prices" (HICP) (the annual average rate of inflation for 12 months), in the post-crisis period Bulgaria is experiencing deflation at times, due to the superposition of several unfavorable factors in the economy, but generally speaking Bulgaria is far below the reference inflation rate after 2013. Under the criterion of "Budget Deficit", in 2014 Bulgaria exceeds the reference framework, but by 2015 the deficit has stabilized. Government debt in relation to GDP under the Maastricht criteria is also below the reference framework of $60 \%$ of GDP. The long-term interest rates under the Maastricht criteria have also declined in recent years. The exchange rates stability is secured following the adoption of the Currency Board, but the Bulgarian lev which is firmly pegged to the euro probably has a negative impact on the competitiveness of Bulgaria's foreign trade.

The high degree of openness of the Bulgarian economy is the reason why exports play a role in increasing economic growth. The different exchange rate regimes applied by the countries of Central and Eastern Europe have a different impact on the foreign trade in these countries. When there is a decrease in exports, the fixed exchange rate of the lev in relation to the euro does not allow the depreciation of the nominal exchange rate of the Bulgarian lev (BGN) in relation to the euro. The Central European countries and Romania have flexible exchange rate regimes and this allows for maneuvering with the level of the nominal exchange rate when there is a decline in exports or when there is an increase in imports, which limits the contraction of production in the event of crisis tendencies or stagnation. The flexible exchange rate regimes may very well contribute to the more rapid recovery of production in the countries where they are implemented. (ECB, July 2010). 
Table 2. Nominal convergence criteria of Bulgaria and of the countries in Central and Eastern Europe which are not to members of the Euro area as of April 2016

\begin{tabular}{|l|l|l|l|l|l|l|}
\hline Countries & \multicolumn{6}{|l|}{ Reference values/benchmarks } \\
\hline & $\begin{array}{l}\text { HICP } \\
\text { max. } \\
\mathbf{0 . 7 \%} \\
\text { of } \\
\mathbf{0 4 / 2 0 1 6}\end{array}$ & $\begin{array}{l}\text { Budget } \\
\mathbf{( - )} \text { as of } \\
\text { GDP }\end{array}$ & $\begin{array}{l}\text { Domestic } \\
\text { debt \% of } \\
\text { GDP }\end{array}$ & $\begin{array}{l}\text { ERM } \\
\text { II }\end{array}$ & $\begin{array}{l}\text { Long- } \\
\text { term } \\
\text { interest } \\
\text { rate max. } \\
\mathbf{4 \%}\end{array}$ & $\begin{array}{l}\text { Compatibility } \\
\text { of the legal } \\
\text { framework }\end{array}$ \\
\hline Bulgaria & $-1 \%$ & $2,1 \%$ & $26,7 \%$ & No & $2,5 \%$ & No \\
\hline Croatia & $-0,4 \%$ & $3,2 \%$ & $86,7 \%$ & No & $0,3 \%$ & Yes \\
\hline $\begin{array}{l}\text { Czech } \\
\text { Republic }\end{array}$ & $0,4 \%$ & $0,4 \%$ & $41,1 \%$ & No & $0,6 \%$ & No \\
\hline Hungary & $0,4 \%$ & $2,0 \%$ & $75,3 \%$ & No & $3,4 \%$ & No \\
\hline Poland & $-0,5 \%$ & $2,6 \%$ & $51,3 \%$ & No & $2,9 \%$ & No \\
\hline Romania & $-1,3 \%$ & $0,7 \%$ & $38,4 \%$ & No & $3,6 \%$ & No \\
\hline
\end{tabular}

Source: Compiled with data from: Convergence report, June 2016, European Commission, European Economy, Institutional Paper 026

According to the Convergence Report (June 2016), other factors are also included in nominal terms, such as: the evolution of the balance of payments, the development and integration of markets, the trade balance and the capital account from 2013 to 2015 .

Bulgaria follows the convergence criteria relatively well in the period $2014-2016$, as the inflation rate in the country decreases to deflation, but these levels correspond to the inflationary levels in the euro area. The budget deficit is also decreasing. Bulgaria does not participate in the Exchange rate mechanism II, although the exchange rate of the lev is irreversible pegged to the euro. After 2014, the economic environment is improving and the observed trend in economic activity begins to gain momentum once again in most of the EU Member States - a process that has a positive effect on the Bulgarian economy. This reflects the impact of the rising real disposable income, supported by the absence of inflation and the economic stabilization in the euro area countries, provided that Bulgaria does not have a monetary policy. The nascent recovery leads to some improvement in labor market conditions, but unemployment rates in Bulgaria remain high. It should be noted that in the IT sector, as well as in the business services sector, activity is expanding due to the influx of foreign 
companies in this segment of the market, but there are not enough highly qualified specialists. In this respect, there has been some progress in terms of the compensation of external imbalances, as well as a decrease in the hazards and the vulnerability of the Bulgarian banking sector, which was negatively affected by the bankruptcy of the Corporate Commercial Bank (CCB).

As of 2016, Bulgaria is following the criterion of "price stability", as the 12-month average inflation rate was below or in several instances even below the reference value of $0.7 \%$. Bulgaria, as previously mentioned, reports a negative inflation rate. Regarding the criterion of the government budgetary position, in 2015 the general government balance in all countries that are not members of the euro area (with the exception of Croatia) is level with, or below the deficit reference value of $3 \%$ of the GDP. In 2015, the debt in relation to the GDP was below $30 \%$, and the debt itself was well below the values registered in other countries which are not part of the euro area. With regard to the convergence of long-term interest rates, similar to 2014, in these countries the long-term interest rates were below the reference value of $4 \%$. In Bulgaria, the long-term interest rate stood at $3.5 \%$ throughout the May 2013 - April 2014 period and at 2.5\% throughout the May 2015 - April 2016 period (ECB Report on convergence, June 2016, p. 50).

It is stressed that the Bulgarian economy and finances are integrated with the euro area through trade, investment and through foreign subsidiary banks, which operate on the Bulgarian banking market. There is still uncertainty in the financial sector, intercompany indebtedness remains high and the labor market is subject to limited regulation.

\section{THE REAL ECONOMIC CONVERGENCE OF BULGARIA}

The question remains whether the compliance with the Maastricht criteria (the nominal macroeconomic variables) is a sufficient condition for the convergence of the Bulgarian economy with those of the countries that are farther ahead in their EU integration process than 
Bulgaria? The answer to this question reveals the degree of the real economic convergence of Bulgaria in the EU.

Real economic convergence is aimed at forming similar economic structures in Europe. In the economic literature devoted to economic growth, real economic convergence is known generally as $\beta$ convergence and $\delta$-convergence. The first type ( $\beta$-convergence) is the catching-up of the relatively less developed economies to the developed economies. This means that countries where incomes are lower should achieve higher economic growth and the income levels should become close to those of the wealthier EU countries. A known measure of $\beta$-convergence is the relative GDP per capita, calculated based on the purchasing power standards (PPS).

The second concept ( $\delta$-convergence) is expressed by reducing the dispersion in the level of income in the different EU countries. This means that a less developed economy should achieve higher sustainable economic growth compared to that of the developed economies, so that the incomes in the countries in the regional bloc converge after a certain period of time. The Member State have to raise the GDP per capita, in accordance with the $\beta$-convergence, while the $\delta$-convergence expresses the effects of the rise in the relative GDP per capita of the less developed economy. Sustainable real convergence is a process in which the GDP per capita of a country with a lower income rate really catches up and becomes closer to that of the more developed economies. Real economic convergence is a precondition and a requirement for economic integration because income convergence means sustainable economic growth and the ability of the less developed economy to counteract external shocks. (ECB Economic Bulletin, Issue 5/2015 - Article p.30)

The EMU changes the process of income convergence in the euro area. The GDP growth per capita is unsustainable due to the fact that the asymmetric external shocks cannot be countered with the tools of domestic monetary policy. The reduction of the differences in the interest rates margin of the ECB does not allow for maneuvering with interest rates at the national level, and this also hinders the process of catching-up and convergence of the EU economies. 
In the 1999-2014 period, according to the ECB, 2 there was no improvement in the real convergence among the 12 countries that adopted the euro before 2002, but at the same time signs of cohesion and real convergence can be seen between the euro area countries and the countries that adopted the euro after 2002. (Real convergence in the euro area. p.31-32) This is probably due to the fact that economically developed countries have similar economic structures and convergence there has been more effective after the entry into force of the Single Market. Estonia, Latvia, Lithuania, Romania and Slovakia are successful in the process of catching-up and seek to substantially converge with the average level of real economic convergence in the EU. In the medium term, the real convergence of the EU countries continues to be a determining factor in the economic strategy and policy undertaken by the new EU Member States, including Bulgaria.

Bulgaria's economic growth is closely tied to the economic and social development of the EU. The economic growth in Bulgaria in the years before the economic crisis is positive and fluctuates around 5\%, but the real GDP in Bulgaria increases by $2.3 \%$ throughout the period 2006-2015 and by only about 1.5\% throughout the period 2011-2015. It is higher than the average level for the euro area countries, but it does not contribute significantly to the reduction of the gap in the economic field. As previously highlighted, Bulgaria follows the Maastricht criteria; it intends to join the exchange rate mechanism II (ERMII) and to become a member of the euro area. In this regard, the fulfillment of the nominal criteria is necessary, but the matter of the real economic convergence of Bulgaria in the EU remains important as well.

The comparison between the GDP per capita based on the PPS of the EU Member States from Central Europe with that of Bulgaria shows that this indicator raises the most in Poland and Slovakia in the 20042015 period. During this period, the GDP per capita remains at virtually the same level in Hungary and the Czech Republic. This indicator rises by several percentage points in Bulgaria, which shows that the country is lagging behind in comparison with the countries of Central Europe. The GDP per capita in Bulgaria amounts to $41.2 \%$ out 
of $100 \%$ in the euro area, while in the period $2011-2015$ it is $42.7 \%$. (Figure 1).

Figure 1. GDP per capita based on purchasing power standards (PPS)

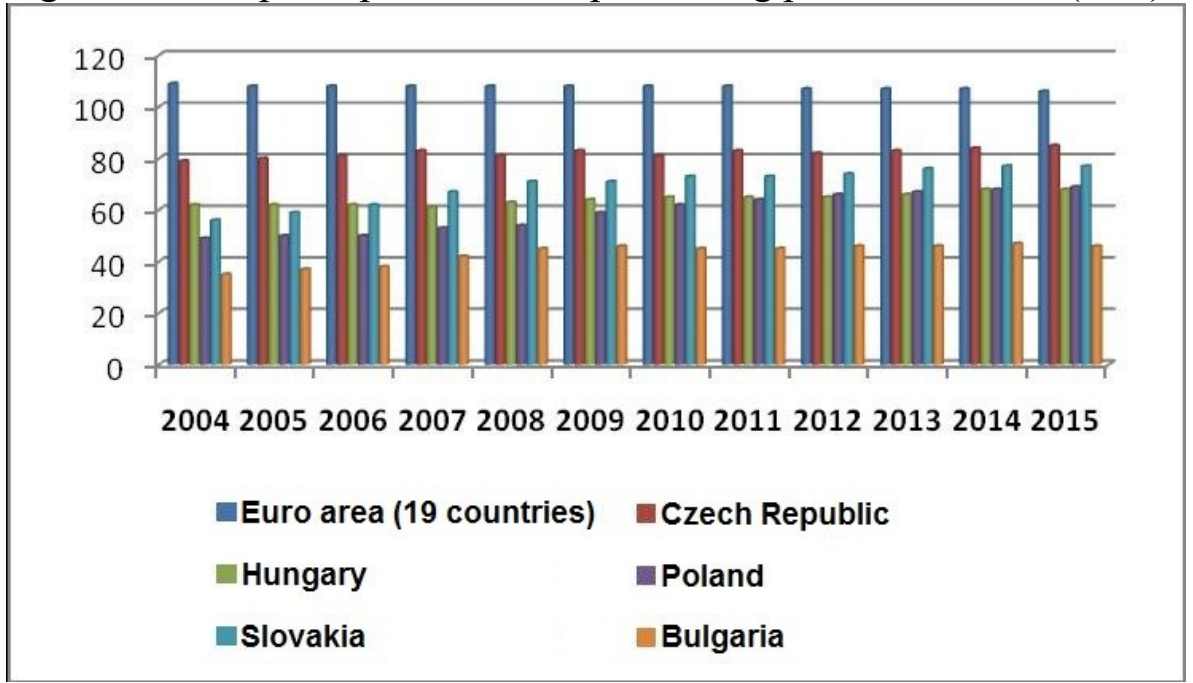

EU28 = 100 annual data for the 2004-2015 period

Source: Eurostat

Romania and Bulgaria have been members of the EU for 10 years now, but in terms of the indicator of GDP per capita based on PPS they are significantly lagging behind the average level of the euro area countries. Nevertheless, the GDP per capita is growing faster in Romania and Romania is coming close to the level of the Central European EU Member States. This shows that the income convergence process of Romania with the EU is relatively more successful in comparison to that of Bulgaria. (Figure 2) 
Figure 2. GDP per capita based on PPS for the euro area countries (19 countries), Bulgaria and Romania for the period 2004-2015

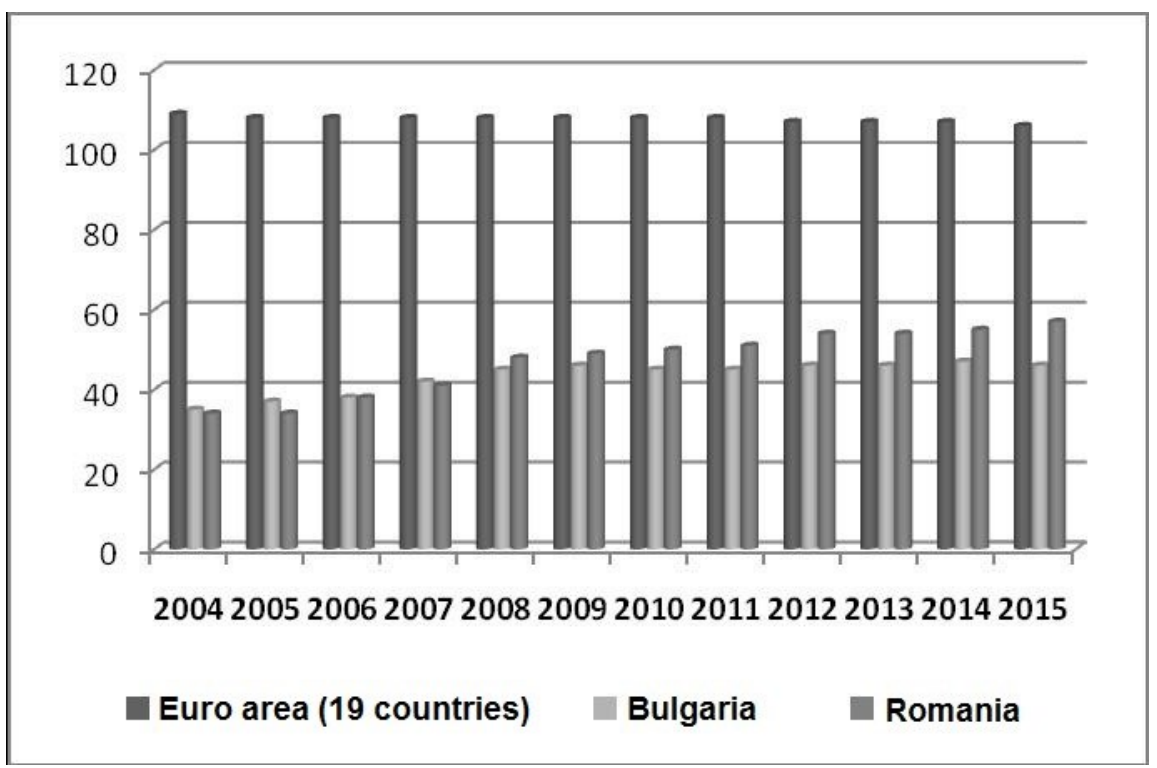

Source: Eurostat

The rising rates of economic growth are having a positive impact on the production and consumption of goods and services. They should grow faster in a weaker economy in comparison with the development rates of production in a developed economy. The aim is the convergence of the levels of production and consumption in the EU. The basis for this assertion lies in increasing the labor productivity and the added value created by a worker in 1 hour of work. The real change in labor productivity demonstrates the capability of the country for economic convergence.

After Bulgaria became an EU member, some improvement could be seen in the key indicators that are relevant to the improvement of labor productivity in the Bulgarian economy, such as the real GDP, the GDP per capita, the relative price level, the wages per employee, etc. The data show that the unit cost of labor in Bulgaria amounted to $5.8 \%$ throughout the period 2006-2015 and that it fell to $3.6 \%$ in the period 2011-2015 (Data from the ECB). On the other hand, the labor 
productivity in the period 2006-2015 totaled $2.4 \%$, while in the period 2011-2015 it declined. (Figure 3)

Figure 3. Unit cost of labor in the Bulgarian economy; Compensation per employee for the entire economy; Labor productivity for the entire economy; annual percentage change

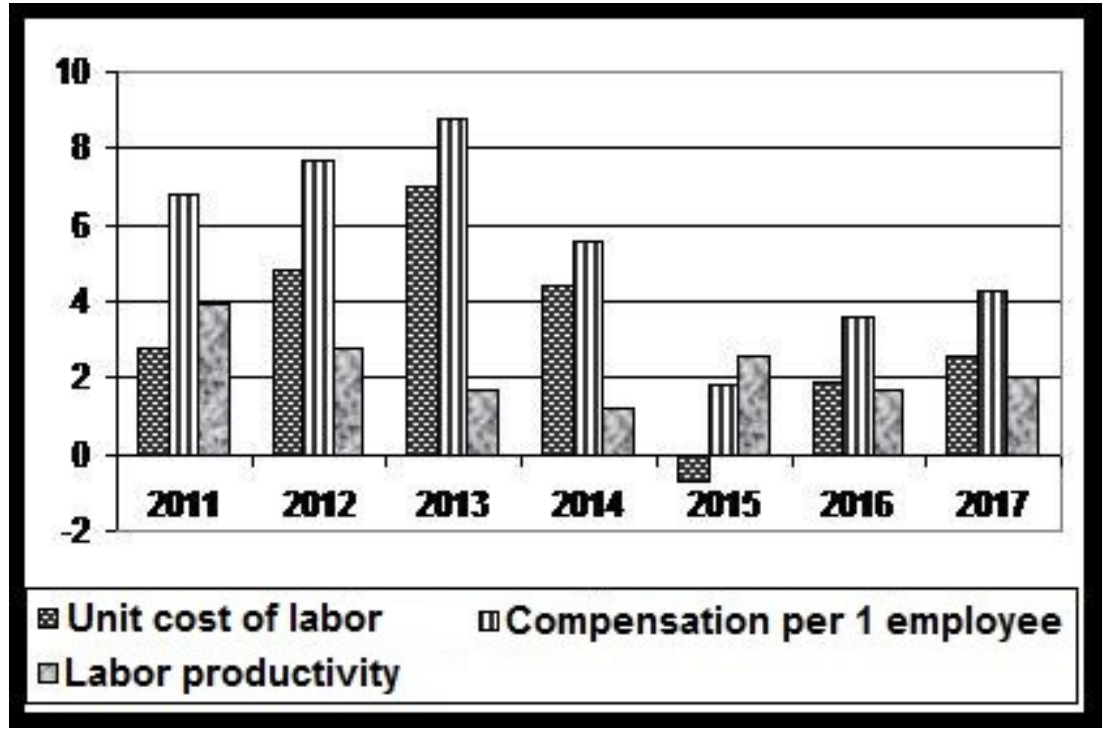

Source: ECB. Convergence Report June 2016, p.72

The low labor productivity is an obstacle to the process of the income convergence of Bulgaria with other EU countries. Bulgaria's membership in the EU is clearly not a fundamental factor that will automatically lead to an improvement in labor productivity. What matters are other factors related to the structure of production and the prospects for its development. The pace of economic growth, though positive, cannot compensate for the imbalances accumulated in the economy in the past and it cannot boost productivity.

The World Bank report for 2015 emphasizes that the labor productivity of the Bulgarian economy is the lowest in comparison with those of the countries of Central and Eastern Europe (Croatia, Czech Republic, Estonia, Hungary, Latvia, Lithuania, Poland, Slovakia, Slovenia and Romania) and that it is below the average level 
of labor productivity for the entire EU. (Productivity in Bulgaria, Trends and Options).

Raising labor productivity is a function of several factors such as demographic trends, indicators of workforce qualification and level of innovation and new technologies in the industry. Due to the negative demographic indicators in Bulgaria, improving labor productivity depends on the implementation of effective and innovative production and instead of only relying on the expansion of the services sector in the domestic economy.

The improvement of labor productivity is closely connected to: the improvement of the quality of education (particularly that of primary and higher education, for which effectiveness is still a challenge); stimulating lifelong learning; the introduction of innovative techniques in the real sector, etc. If enterprises overcome the misallocation of resources on the company level and on the sectoral level, they would be $100 \%$ effective and labor productivity in the industry could grow to up to $80 \%$. (Productivity in Bulgaria, Trends and Options)

The convergence of incomes and the improvement in labor productivity affect the dynamics of the convergence of price levels in Bulgaria in comparison to those of other EU countries. In the shortterm, fluctuations in the nominal exchange rate, the changes in food prices and the effective use of resources affect inflation differentials, which in turn prevents price convergence. Some structural factors, such as trade liberalization and competition in the commodity markets also affect real convergence. Standing at $100 \%$ for the euro area, the price level in Bulgaria increases from 47.5\% in the period 2006-2015 to $48.3 \%$ in the period 2011-2015. The unit cost of labor is an indicator for defining the competitiveness of production. Data show that the unit cost of labor rose to a greater degree than labor productivity in the period 2011-2014, and that it decreased in 2015 . (Figure 3)

Compared to other countries in Central and Eastern Europe, it would seem that wages in Bulgaria are growing at a higher rate even when they are not consistent with labor productivity. Wage growth is higher 
compared to the growth in labor productivity, which affects the level of cost competitiveness.

At first glance it would seem that Bulgarian external competitiveness is influenced positively by the low level of wages in the EU. According to data from 2013, the average hourly pay for work done in the EU-28 (excluding wages in agriculture and public administration) amounted to $€ 23.7$ for the EU and $€ 28.4$ in the euro area countries (17 Member States (EU17). The average hourly pay per man-hour in the EU does not reflect the significant differences that exist between the countries. In Bulgaria, one unit of work done is paid an average of $€$ 3.7, while in Romania it is paid an average of $€$ 4.6. Calculated based on the purchasing power standards (PPS), wages in Bulgaria amount to $37 \%$ of the EU average. The low hourly wages of labor in Bulgaria do not mean that the country earns good competitive positions against counterparties in the EU, because the level of labor productivity in Bulgaria.

The index of the physical volume of production decreased in 2016 (second quarter), but since the beginning of 2016 the indicator of GDP per man-hour has improved in comparison to the fourth quarter of 2014. The gross value added (GVA) per 1 man-hour is also increasing, which gives grounds to assume that in some sectors of the economy wages are beginning to rise, while still keeping in mind that they are the lowest in the EU. (Figure 4) 
Figure 4. Real volume index $2010=100$, in \%; GDP per 1 man-hour, real volume index $2010=100$, in $\%$; GVA per employee, real volume index $2010=100$, in $\%$; GVA per man-hour, real volume index $2010=$ 100 , in \%. (Tp1, 2 means first quarter, second quarter, and so on/etc.)

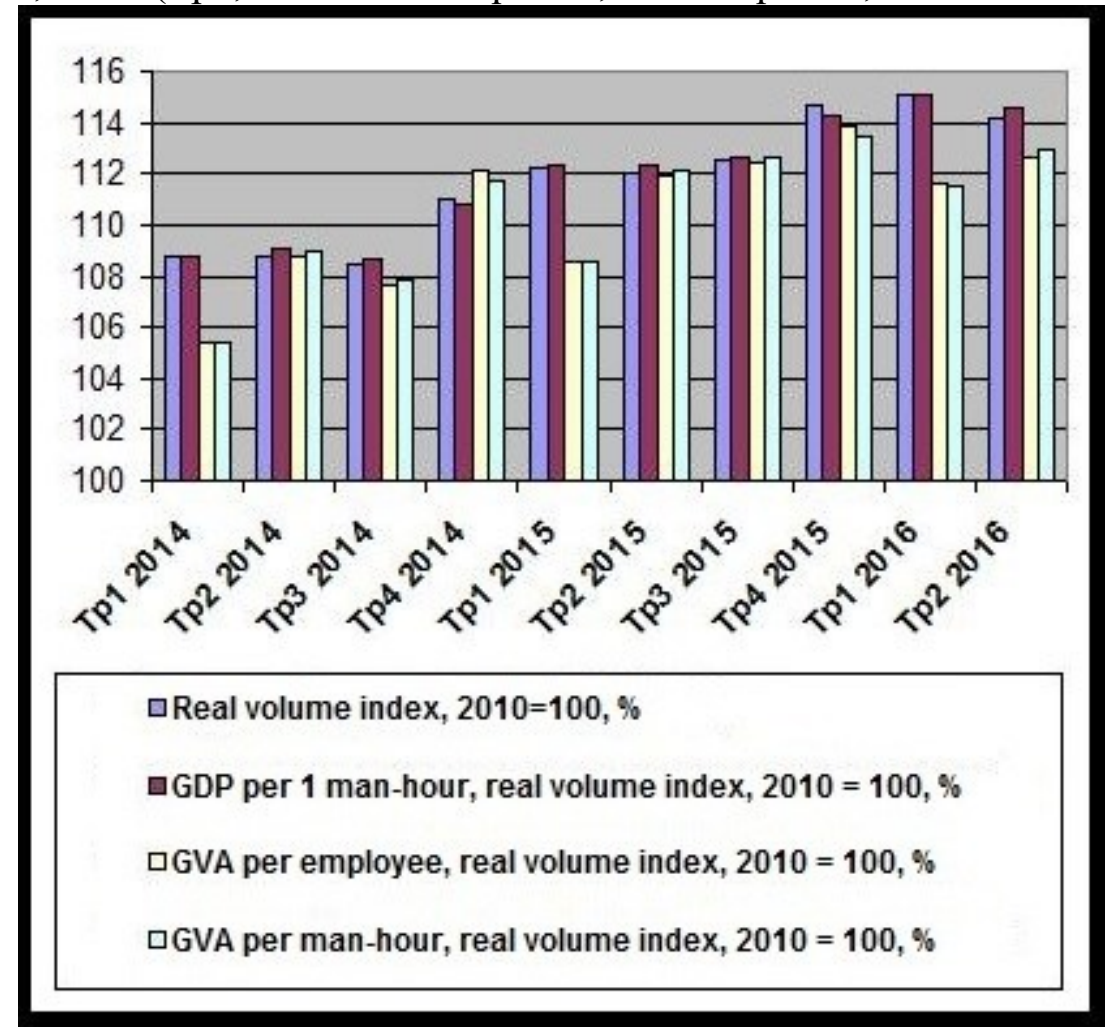

Source: NSI

The increase in the unit cost of labor does not affect the foreign trade of Bulgaria. This is due to some improvement in the indicators characterizing the external competitiveness of Bulgarian exports. The growth of the GVA per man-hour is compensated for by the effects of non-price factors such as improving the quality of products for export, the availability of favorable export prices and reductions in the prices of oil and basic raw materials for the production of goods, etc.

The appreciation of the equilibrium real exchange rate shows that convergence is taking place at the price level, which is the consequence of economic catch-up (De Grauwe and Schnabl, 2005). 
The real effective exchange rate (REER) (or the relative indicator of price and cost, which measures competitiveness against the key competitors of the country on the international markets. The REER depends not only on changes in the exchange rates, but also on trends in prices and costs. The REER in Bulgaria began to deteriorate after 2009. In recent years, the level of this index for Bulgaria has increased by $60 \%$ in comparison to the levels in 2005 , when it was adopted as being $=100$, which means that the competitiveness of Bulgaria is deteriorating in comparison to its level before the crisis and in comparison to the competitiveness of the countries of Central Europe and Romania. (Figure 5)

Figure 5. Real Effective Exchange Rate (REER) in relation to the 37 trade partners of Bulgaria, euro area - 19 countries, the Czech Republic, Hungary, Poland and Romania. $(2005=100)$. The rise in the index means a drop in competitiveness.

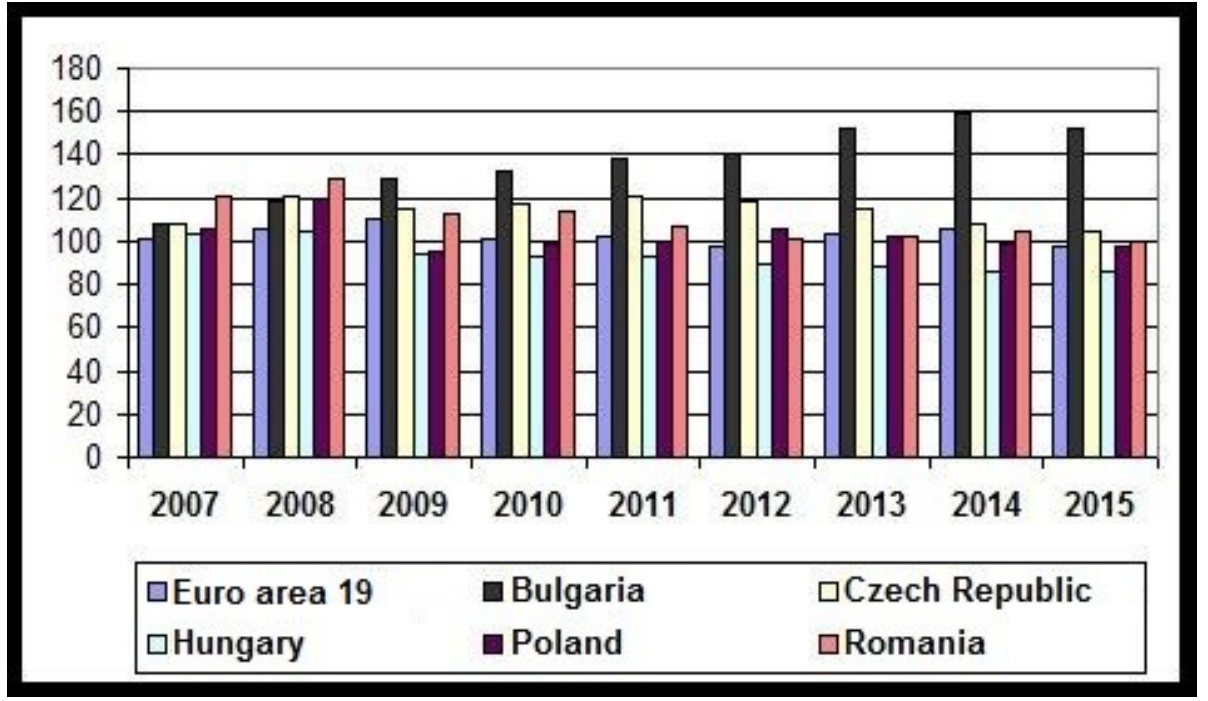

Source: Eurostat

The deteriorating position of export competitiveness shows that Bulgaria still has not overcome the macroeconomic imbalances accumulated as a result of the economic crisis. The strictly fixed exchange rate of the lev under the rule of the Currency Board does not allow exchange rate fluctuations in order to gain competitive 
advantages. It cannot be assessed to what extent the domestic firms that work for export are experiencing the pressure of changes in international prices and what the possible future costs conclusions that can be made are. The movements of the REER, which show the deterioration in competitiveness, suggest that the process of the real economic convergence of Bulgaria is slowing down. For Bulgaria, improving the labor productivity and the competitiveness of production is an important challenge for its economic catching-up within the EU, as well as in comparison with the Central and Eastern European EU Member States.

\section{MAIN FINDINGS}

Economic convergence and the convergence of economies are a complex economic and political objective, which is difficult to assess. The convergence of economies, the economic catch-up and the convergence are seen, in the context of their evaluation, in nominal and in real terms. The changes in the main macroeconomic variables are essential when a Member State enters the ERM II and, respectively, adopts the euro. In essence, the EMU proves to be unequipped to counter the economic and sovereign debt crisis. The freezing of wages (or internal devaluation), which is the preferred mechanism for the correction and balancing of the economy, in actuality creates deflation. There is growing pressure on European economies and the real economic convergence is being hindered.

Bulgaria has strictly followed the Maastricht criteria for years and has stated its intention to become part of the euro area. The process of real economic convergence shows that Bulgaria is lagging behind other EU countries in terms of GDP per capita, improving labor productivity and convergence of income. Despite Bulgaria's efforts to stimulate economic growth and labor productivity, the improvement of the competitiveness of the Bulgarian economy depends on the processes that are undergoing development in the EU. Bulgaria's membership in the EU does not mean an automatic and rapid economic convergence. As stated, the Member States are part of different business cycles and they have varying degrees of economic and social development. The process of income convergence is a 
function of the improvement in labor productivity and of the increase in the competitiveness of products in foreign markets. The country should implement targeted policies in all areas of the economy in order to provide the necessary support for stimulating the process of income convergence. The development of an efficient industry and the application of innovative technologies, combined with investment in the education and skills of the labor force are a priority. The deepening of the differences in the economic development and the economic business cycle does not allow mechanical cohesion, because the results can backfire and strengthen divergent economic factors, which does not contribute to real economic convergence between the countries.

\section{LITERATURE}

1. Dauderstadt, M., October 2014, Convergence in Crisis, European Integration in Jeopardy, Friedrich Ebert Stiftung, International Policy Analysis.

2. De Grauwe, P., Schnabl G. (December 2004), Nominal versus Real Convergence with Respect to EMU Accession EMU Entry Scenarios for the New Member States.

3. Macroeconomic Imbalances, Bulgaria, 2014, (March 2014), European Economy, Occasional Papers 173, EU, ecfininfo@ec.europa.eu p. 1-39.

4. European Commission In depth review for Bulgaria, (2012) European Economy, Occasional Paper 209

5. Andor L, (24.10.2014), Cohesion and Convergence in Europe, Lecture at Warsaw School of Economics.

6. Bartosz J, H. Ponikowski, (July 1-2, 2014) Real convergence, economic crises and EU cohesion policy, Cambridge Conference Business\&Economics, Cambridge, UK.

7. ECB Economic Bulletin, Issue 5 / 2015 - Article p. 30

8. Real convergence in the euroarea, evidence, theory and policy implications, (2015), ECB Economic Bulletin, Issue 5.

9. Christova-Balkanska I., Economic Development of Bulgaria and Romania in the Post Crisis Period (2014) Journal Of Financial and Monetary Economics, 1, Annual Review, "Victor Slavescu" Centre for Financial and Monetary Research http://jfme.icfm.ro 
10. "Bulgaria: A Program for Financial Sector Assessment - a detailed assessment of the compliance with the Basle Core Principles for Effective Banking Supervision", October 2015, Country report № 15/295, IMF.

11. Productivity in Bulgaria, Trends and Options, June 2015, Document of the World Bank, pp.1-137.

12. ECB. Convergence Report June 2016 